\title{
Employability, Services for Unemployed Job Seekers and the Digital Divide
}

\author{
Colin Lindsay \\ [Paper first received, March 2004; in final form, June 2004]
}

Summary. Providing accurate and accessible labour market information is a key priority for policies targeted at improving the employability of unemployed people. In an attempt to develop the quality and reach of such services, policy-makers are increasingly turning to ICT, and particularly the Internet. However, there are concerns that the expansion of services delivered through ICT risks leaving behind the most disadvantaged. This paper investigates the current and potential role of ICT within the job-seeking activities of unemployed people in one urban labour market (the city of Glasgow). Deploying the concept of the 'digital divide' as an analytical framework, it examines differences between job seekers' access to, and use of, the Internet. The paper finds an association between higher levels of economic capital (income) and cultural capital (skills) and Internet access and job seeking. It is argued that a renewed commitment to the development of community-based technology centres and ICT training for the unemployed is required, if disadvantaged job seekers are to reap the potential employability gains associated with the expansion of on-line services.

\section{Introduction}

Providing accurate and accessible labour market information is a key priority for policy-makers concerned with improving the employability of unemployed people. In an attempt to develop the quality and expand the reach of services for job seekers, policymakers have promoted solutions delivered through information and communications technologies (ICT). (ICT is here defined as computing and telecommunications hardware, applications software and services in the relevant policy area, specifically telephone, Internet or other computer-mediated tools or services.) The potential benefits are clear: it is suggested that ICT-based services have the capacity to overcome problems of distance and remoteness; provide more accurate and detailed labour market vacancy information; deliver a more responsive and interactive model of service provision; and promote social networking among disadvantaged groups.

However, there are concerns that the expansion of services delivered through new technologies risks leaving behind the most disadvantaged, who are less likely to have the access and skills required to exploit the potential benefits associated with ICT. This paper seeks to investigate the current and potential role of ICT within the job-seeking activities of unemployed people in one urban labour market (the city of Glasgow) and to discuss the value of ICT-based services in enhancing the employability of job seekers. Deploying the concept of the 'digital divide' 
as an analytical framework, it examines differences between job seekers' ability and inclination to use ICT-based services.

Following this introduction, section 2 of the paper discusses the impact of ICT on the social inclusion and employability policy agenda and outlines the value of the concept of the 'digital divide' as a means of exploring individuals' experiences of ICT-based services. Section 3 provides information on the study area and methodology. Section 4 analyses job seekers' search strategies, their use of, and attitudes towards, ICT-based services and the extent to which a digital divide affects the most disadvantaged. Section 5 draws conclusions from the preceding analysis and discusses policy implications.

\section{ICT, Employability and New Services For Job Seekers}

\subsection{ICT, Social Inclusion and Employability}

Policy-makers are increasingly turning to ICT, and especially the Internet, to deliver services for disadvantaged groups. To some extent, this shift in policy reflects a general belief in the potential for new technologies to promote social inclusion, based on the idea that

ICT can have a far-reaching impact on the quality of life of marginalised segments of the population, by providing more responsive and transparent governance as well as improving the reach and delivery of health, education and other social services (ILO, 2001, ch. 6, part 6.6).

In the area of service delivery, it is argued that ICT has the capacity to increase the dynamism of both consumer and public services (Dabinett, 2002) and that the Internet in particular will facilitate a more interactive relationship between public service providers and their clients, possibly resulting in the development of more responsive, local services from the 'bottom-up' (Loader et al., 2002).

Furthermore, the Internet potentially has an important role to play in widening access to social networks-particularly important for unemployed people given the significance of networking within the job-search process (Chapple, 2002; Lindsay et al., 2003). Even basic forms of ICT (such as telephone access) can play an important role in facilitating social networking among disadvantaged groups (Haddon, 2000) and it has been suggested that the Internet may be able to act as an effective network-building tool for vulnerable people who would otherwise struggle to form social relationships (McKenna and Bargh, 2000; Katz et al., 2001). There is evidence that those who become involved in the exchange of ideas and information on-line can often transfer their 'virtual' activities and relationships to the 'real world'. Internet interactions can fill the gaps left by a lack of face-to-face contacts and can also lead to the expansion of personal networks (see for example, Wellman et al., 2001). In this way, ICT has the potential to supplement 'participatory' social capital, empowering the individual and countering the characteristic localism of life in disadvantaged urban areas (Carter and Grieco, 2000; Wellman, 2001; Hampton, 2002).

The rise of the Internet as both communication tool and service delivery device has wider implications for the employability policy agenda. The ability to use ICT is increasingly viewed as a 'key transferable skill' (McQuaid and Lindsay, 2005). For many employers across a range of sectors, these skills are an important component of employability (Johnson and Burden, 2003; Belt and Richardson, 2005). Furthermore, there is some evidence that the introduction of Web-based job seeking can impact on the overall efficiency of the job-matching process, by increasing the number and quality of potential matches between employers and job seekers-labour market theory predicts that such an improvement in the 'reservation match quality' will eventually result in broader productivity gains (Autor, 2001).

Given these potential benefits, the UK government's current Public Service Agreement aims for 100 per cent capability to deliver 
e-enabled services by 2005 -i.e. all major central government information services should be available via ICT by this target date (Cabinet Office, 2002). Policy-makers at the Scottish and UK level have also committed substantial resources to 'digital inclusion' initiatives, with the establishment of an 'electronic library network' and ICT learning centres a particular priority. Targeted, area-based policies have sought to apply ICT to the particular problems of disadvantaged urban communities. For example, the 'WiredUp Communities' initiative (and the equivalent 'Digital Communities' in Scotland) has provided broadband Internet access, digital television, mobile and standard telephone links and advice and support services for all citizens in selected pilot neighbourhoods, including a number of urban areas (DfES, 2002; Scottish Executive, 2002). The objective is to assess how individual access to the Internet can transform opportunities for people living in these communities by developing new ways of accessing learning, work and public services. Evaluation evidence from the WiredUp Communities initiative suggests that the take-up of Internet services has varied widely between and within communities, with overall Internet service use in pilot areas ranging between 50 per cent and 90 per cent. Across all areas, one-quarter of those provided with home Internet access did not use Web-based services at all (Devins et al., 2003).

In the specific area of job seeking and services for the unemployed, the Internet and other new forms of ICT provision have come to play an increasingly important role. There is some evidence that the use of new technologies by service providers has had a positive impact on the take-up of welfare benefits (Davies, 2002), while in the UK the public employment service, Jobcentre Plus, has promoted its 'Internet job bank' and 'Jobseeker Direct' national telephone helpline as important supplementary services throughout the country, and as its primary means of contact with job seekers in many rural areas. The development and expansion of telephone and Internet-based services are a core component of the agency's continuing reform programme, 'Modernising Employment Service' (Employment Service, 2000). The Jobcentre Plus website has provided job-search services since November 2000. However, the website's database has also become familiar to job seekers using the national Jobcentre network, due to the recent introduction of ICT-based systems into local offices in the form of computerised 'Jobpoints'. Between April 2001 and February 2002, 9000 of these touch-screen kiosks (which allow job seekers to carry out searches by area and occupation using the same national jobs database found on the Jobcentre Plus website) were placed in over 1000 Jobcentre offices nationwide.

The development of telephone-based services has provided another focus for Jobcentre Plus. Following a pilot programme started in January 1999, the 'Jobseeker Direct' national telephone helpline became a permanent component of Jobcentre Plus provision in March 2000. During 2001/02, the service received 4.5 million calls, resulting in almost 4.4 million referrals and 115000 job entries (DWP, 2002). However, there is evidence that the introduction of the Jobseeker Direct service has had little impact on the regularity with which most unemployed people use Jobcentre offices and that the vast majority of users live within a 30-minute travelling distance of their local Jobcentre office (GHK, 2002a). Similarly, evaluation evidence suggests that the Web-based services offered by Jobcentre Plus tend to be viewed as userfriendly, but have not yet been associated with greater job-search effort, efficiency or success (GHK, 2002b). Furthermore, Jobcentre staff appear to have mixed views regarding the effectiveness of Internet job-search services delivered on site at Jobcentre offices, with time savings provided by ICT counteracted by some problems in operating new systems (GHK, 2002c).

Relatively little research has been undertaken into the wider impact of ICT on the job-search process from the perspective of the job seeker. The majority of those in work, with access to ICT and looking for 
work appear to use the Internet as a job-search tool (Freeman, 2002). There is also evidence that, given new opportunities to access ICT, the majority of users in disadvantaged communities will undertake 'labour market search' (employment or training) activities (Devins et al., 2003). However, McQuaid et al. (2003) argue that, while ICT-based job seeking appears to be growing in importance (especially in rural communities and other areas with weak formal service infrastructures 'on the ground'), informal, face-to-face networking and other traditional methods continue to dominate. For those using formal Web-based services, on-line search engines would appear to offer a useful addition tobut not a replacement for-local services and personal contacts (see Kuhn and Skuterud, 2000, for a US perspective). Niles and Hanson (2003) similarly note that, although the Internet has provided employers with a new tool for screening job applicants, 'grounded social relations' (existing social networks) continue to define the job-search and recruitment processes.

Concerns have also been raised that the expansion of ICT-based services for job seekers risks 'leaving behind' those most in need of assistance (McQuaid et al., 2004). In more general terms, despite a wave of 'techno-optimism' in the early 1990s, more recent analyses of ICT access and use in both urban and rural areas suggest that claims that the Internet will revolutionise service delivery are at best premature (van Winden, 2001; van den Berg and van Winden, 2002; Malecki, 2003). Indeed, it has even been suggested that, as the role of ICT in service provision continues to expand, the exclusion experienced by disadvantaged groups may be accentuated and reinforced, rather than mitigated (Corrigan and Joyce, 2000).

\subsection{Conceptualising the Digital Divide}

Much of the concern raised over the expansion of ICT-based services relates to the apparent divide between those who are able to exploit the benefits of new technologies and those who are not (with the latter group typically experiencing other forms of social and economic exclusion). The problem has been characterised as a 'technology gap' (Servon and Nelson, 2001), a 'knowledge gap' (Bonfadelli, 2002) and most commonly and effectively as a 'digital divide' (OECD, 2001; DTI, 2000). The OECD has defined the digital divide as

The gap between individuals, households, businesses and geographical areas at different socioeconomic levels with regard both to their opportunities to access ICT and to their use of the Internet for a wide variety of activities (OECD, 2001, p. 5).

With the rapid expansion of Internet-based services since the 1990s, concern has increasingly focused on the emerging digital dividethe divide between 'information haves' and 'information have-nots' (NTAI, 1999, 2000; Parker, 2000; Norris, 2001).

However, although the dichotomous characterisation of a digital divide separating 'haves' and 'have-nots' has starkly focused attention on the scale of the problem, it has also arguably led to an oversimplification of the debate, where 'improving access' to ICT is seen as a panacea for social and labour market exclusion (Selwyn, 2002a). The reality is that how individuals use and relate to ICT, their awareness of services provided through ICT and how those services are delivered will all impact on the capacity of new technologies to facilitate employability and social inclusion (Servon, 2002; van der Meer and van Winden, 2003). From the individual's perspective, Selwyn (2002b) identifies three forms of 'technological capital' that define experiences of the digital divide

-Economic capital: material resources such as usable space for ICT use in domestic, community and work settings; free time for ICT use; the economic capacity to purchase ICT software and hardware for personal use. - Cultural capital: the individual's ICT skills; their willingness and ability to develop their ICT skills and knowledge; 'self-image' as an ICT user; the extent of socialisation into a 
'techno-culture' through access to goods and services, and through contact with other ICT users.

- Social capital: the extent and range of networks of 'technological' contacts (others with knowledge of and access to ICT); the extent and range of face-to-face contacts (friends, family, social groups); the extent and range of 'remote' contacts (access to and awareness of on-line services and facilities).

Clearly, whatever the socio-cultural dynamics, access to economic capital is likely to impact on the capacity of individuals to exploit ICT. The rise of the Internet, like the introduction of many forms of new technology, has arguably tended to benefit the least disadvantaged, while large numbers of individuals continue to be excluded as a result of their financial status (Servaes and Heinderyckx, 2002). Those in lower income-groups are generally less likely to have access to a PC and/or the Internet at home-for example, at the time when the research discussed below was carried out (in 2003), an average of 47 per cent of all UK households had Internet access, compared with only 12 per cent of the poorest tenth of households (ONS, 2003).

Beyond simple issues of access to ICT, aspects of cultural capital will define how individuals interact with new technologies. For those not using ICT to look for work, a real and perceived lack of skills would appear to be a major barrier (McQuaid et al., 2003). However, the conceptualisation of cultural capital seeks to go further than simple 'human capital' or skills-based analyses. According to this argument, a crucial aspect of the digital divide lies in the individual's self-perception as an ICT user (which can be independent of objective measures of ICT skills) and their sense of belonging to 'electronic networks' or 'digital communities' that socialise regular ICT use (Wellman et al., 2001; Borgida et al., 2002). At the individual level, it has been suggested that a distinction can be drawn between 'enthusiasts, pragmatists and e-reluctants' —with the latter term describing those who are least likely to engage in e-learning activities or use e-services (KPMG, 2002). Furthermore, research undertaken on behalf of the Department for Work and Pensions confirms that unemployed people are more likely to fall into the 'e-reluctant' group-they are far less likely to take advantage of the ICTbased services offered by Jobcentre Plus than other members of the labour force using the agency to move between jobs (Coleman et al., 2002).

This failure of many unemployed people to develop the 'self-image' of an ICT user can partly be explained by the form and content of many technology-based services. Recent research suggests that the learningcentred approach to bridging the digital divide favoured by policy-makers has enjoyed some success, but also highlights the predictable reluctance of many among the most disadvantaged to engage in structured, 'classroom'-style learning (Devins et al., 2002). Meanwhile, the dynamism that was to characterise ICT-based provision has not always been evident, with official information sites and helplines largely continuing to treat the client as a passive consumer of structured services. The 'new form of publicness' (Mansell, 2002)-i.e. the more interactive and participatory approach-promised by e-government has therefore often been marginalised by the managerial model of service delivery promoted by some public agencies (Chadwick and May, 2002).

Finally, aspects of social capital (in terms of the strength and range of social contacts open to individuals on-line and 'in real life') clearly have the capacity to affect the manner in which job seekers relate to ICT. Despite the claims made for the Internet and other forms of ICT as offering new opportunities for networking, there is strong evidence that existing network structures provide the context for the use of 'social technologies' (i.e. ICT used to facilitate social interaction) rather than vice versa (DiMaggio et al., 2001; Borgida et al., 2002). Indeed, Graham (2002) argues that the use of new technologies in service delivery actually restricts social 
interactions, particularly between different income-groups. Similarly, Kraut et al. (1998) and Nie and Erbring (2000) have shown that Internet use has the capacity to displace other forms of activity that can involve a greater degree of immediate social contact, with potentially damaging social and psychological side effects.

Thus, it has been argued that social resources, along with access to cultural and economic capital, shape experiences of the digital divide and define the extent to which individuals are able to benefit from the opportunities associated with new technologies. The same factors will impact on the capacity of individual job seekers to reap the benefits of ICT-based services, designed to improve their employability by facilitating more effective job search and better access to vacancy information and training services. Yet policy-makers continue to view ICT (and especially Internet) services as a core component of their approach to promoting employability. The remainder of this paper investigates whether this is a realistic model for delivering services for job seekers, and hence improving their employability, by examining the role of ICT in the search strategies of unemployed people in one urban area and analysing the economic, cultural and social aspects of any digital divide affecting members of this group.

\section{Study Area and Methodology}

\subsection{The Study Area}

The research reported in this paper was carried out in Glasgow, Scotland's largest city, with a working-age population of approximately 370000 (Scottish Enterprise Glasgow, 2003). The city is centrally located and a major investment and employment hub, accounting for approximately 15 per cent of Scottish GDP (Scottish Executive, 2001). However, in recent years unemployment has remained above that national average. At the time of the research (April and May 2003), registered claimant unemployment was 4.8 per cent, compared with
Scottish and UK averages of 3.2 per cent and 2.6 per cent respectively. Furthermore, claimant unemployment figures mask a more serious problem of pockets of long-term economic inactivity, with large numbers claiming non-work related welfare benefits. A recent estimate placed the 'real level of unemployment' (non-voluntary economic inactivity) at 22 per cent in January 2002 (Beatty et al., 2002).

Despite the availability of broadband connection across the city, levels of home Internet access in Glasgow are relatively low-estimated at just 31 per cent (MORI, 2003). This compares with average access rates of 42 per cent in Scotland and 47 per cent in the UK (ONS, 2003). Internet-linked 'Jobpoint' terminals are available at 22 Jobcentre Plus offices across the agency's 'Glasgow district' area of operation. There are also 93 public Internet access points in the city (based at libraries, learning centres and other locations) providing 851 Internet devices (Scottish Enterprise, 2003). However, it has been suggested that these services remain largely the preserve of those already familiar with the Internet-it is estimated that only 2 per cent of those Glaswegians without access at home use the Internet at public access points (MORI, 2003).

\subsection{Methodology and Sample Profile}

The research was carried out in two areas of Glasgow: Auldhouse in the south-west, and Springburn in the north of the city. Both areas report above-average levels of unemployment and economic inactivity. Partially structured, in-depth interviews were carried out with 220 registered unemployed people at Jobcentre offices in the two areas. The sample accurately reflected the gender balance within the registered unemployed population in Glasgow (80 per cent men and 20 per cent women). The age profile of the sample also reflected the wider registered unemployed population reasonably accurately. Approximately 27 per cent of the sample were in the 16-24 age-group (compared with 24 per cent of the Glasgow 
Table 1. Level of qualification attained by respondents, by unemployment duration (percentages)

\begin{tabular}{|c|c|c|c|}
\hline Qualification level & Duration less than 1 year & Duration at least 1 year & All \\
\hline None $^{\mathrm{a}}$ & 26 & 60 & 37 \\
\hline SCE 'O' grade or equivalent ${ }^{b}$ & 33 & 14 & 27 \\
\hline SCE ' $H$ ' grade or equivalent ${ }^{c}$ & 27 & 13 & 23 \\
\hline Higher education qualification $^{\mathrm{d}}$ & 7 & 9 & 7 \\
\hline Degree or equivalent & 7 & 3 & 6 \\
\hline
\end{tabular}

a 'None' includes those naming vocational qualifications not recognised in the UK Labour Force Survey.

b 'O Grade or equivalent' includes SCE Ordinary and Standard grades, GSVQ, RSA diploma level and SVQ/NVQ levels 1-2.

c 'H grade or equivalent' includes SCE Higher Grade, GSVQ advanced, RSA advanced diploma, SVQ/NVQ level 3.

d 'Higher education qualification' includes HND, HNC, SVQ/NVQ level 4 and professional qualifications.

claimant count); 60 per cent were in the 'core' job-seeker age-group of 25-49 (compared with 59 per cent of the claimant count); and 13 per cent were aged 50 and over (compared with 17 per cent).

However, the long-term unemployed were deliberately overrepresented, to ensure a usable sample for comparing the barriers faced by these and more recently unemployed job seekers. Approximately one-third (33 per cent) of interviewees had been unemployed for more than one year, compared with 16 per cent of Glasgow's registered unemployed. Finally, the educational attainment of both long-term and short-term job seekers within the sample was relatively limited. As Table 1 illustrates, 64 per cent of all respondents were not qualified to SCE Higher Grade level (NVQ Level 3 equivalent), rising to 74 per cent among the long-term unemployed. Only 43 per cent of the general Scottish labour force is similarly unqualified (Futureskills Scotland, 2003).

\section{Findings: ICT, Job Seeking and the Digital Divide}

\subsection{Job-search Methods Used by Respondents}

In order to understand the potential impact of new ICT-based services on the job-search activities of unemployed people, it is necessary first to identify current practice. The evidence suggests that, despite the presence of Internet and telephone provision, remote ICT services continue to play a fairly marginal role in the job-search activities of most unemployed people. As Table 2 illustrates, 31 per cent of interviewees reported using the Internet on a regular (i.e. weekly) basis to look for work, while only 7 per cent regularly used the Jobseeker Direct telephone helpline. Of course, it should be noted that the majority (65 per cent) used Web-linked Jobpoints in Jobcentres on a weekly basis and almost all job seekers had used these touch-screen terminals at some time.

The Internet appears to have been of relatively marginal importance to the job-search efforts of most unemployed people and one tool among many others for those using it to look for work. Internet job seeking was less popular than newspapers, used by 92 per cent of job seekers on a weekly basis, and asking the advice of Jobcentre staff (57 per cent). Job seekers were also more likely to turn to informal methods such as personal contacts (58 per cent) and direct, in-person approaches to employers (44 per cent). Nevertheless, with almost one-third of interviewees using the Internet to look for work every week and 42 per cent using Web-based services at some time, there is some evidence that ICT is playing an increasingly important role in the search activities of the unemployed, particularly given the context of generally low levels of Internet penetration and use in the city of Glasgow (see above).

It is worth noting that those using the Internet to look for work were more likely to turn to private-sector job-search engines or company websites than the Jobcentre Plus 
Table 2. Percentage of respondents using selected job-search methods

\begin{tabular}{lccc}
\hline Job search method & Used at least weekly & Used at some time & Never used \\
\hline Newspaper advertisements & 92 & 4 & 4 \\
Jobcentre Jobpoints & 65 & 34 & 1 \\
Jobcentre staff & 57 & 43 & 0 \\
Personal contacts & 58 & 34 & 8 \\
Direct approach & 44 & 31 & 25 \\
Internet & 31 & 11 & 58 \\
Community organisations & 13 & 15 & 72 \\
Jobseeker Direct telephone helpline & 7 & 17 & 76 \\
\hline
\end{tabular}

Internet database. Of those reporting using the Internet on a weekly basis to look for work, almost three-fifths (58 per cent) used only 'private' job-search sites, compared with only 6 per cent who exclusively used Jobcentre Plus services. A further 36 per cent used both Jobcentre Plus and other search engines. For many of those with experience of looking for work on-line, the Jobcentre Plus website appeared to offer few benefits that were not available when attending Jobcentre offices in person. Given that regular attendance in person at Jobcentres is a condition of receiving unemployment benefits in the UK, many job seekers appeared to be content to use Jobpoints (linked to the agency's on-line database) during these mandatory visits and then turn to alternative search sites when using the Internet at home or other locations. This approach was reinforced by the view expressed by job seekers that not all vacancies are communicated to Jobcentre Plus by employers. This was particularly the case for job seekers seeking better-paid, higher-skilled opportunities. There remains a perception that the vacancies notified to Jobcentre Plus, and appearing on the agency's Internet database, are more likely to be lower-skilled.

There was less evidence of the Internet and other forms of ICT acting as an effective tool for identifying job opportunities. When asked how they identified the last job that they had applied for, only 4 per cent of interviewees named Internet services (although again it should be noted that on-line Jobpoints in Jobcentres were the most important method here, mentioned by 32 per cent). Newspapers
(18 per cent), personal contacts (17 per cent) and Jobcentre staff (13 per cent) were again clearly more important than Internet job seeking, while only one interviewee $(0.5$ per cent of the sample) had identified his most recently pursued opportunity through the Jobseeker Direct helpline (see Table 3).

\subsection{Job Seeking and the Role of ICT: Who and Why?}

Clearly, the figures for ICT-based job seeking presented above mask wide variations between job-seeker groups. First, we would expect home access to the Internet to be associated with Web-based job seeking, particularly given the apparent failure of those without access at home to use community Internet facilities in Glasgow (see section 3). Approximately 28 per cent of interviewees

Table 3. Job-search methods used to identify most recently pursued job opportunity

\begin{tabular}{lcc}
\hline Job-search method & Number & Percentage \\
\hline Jobcentre Jobpoints & 69 & 32 \\
Newspaper & 39 & 18 \\
$\quad$ advertisements & & \\
Personal contacts & 37 & 17 \\
Jobcentre staff & 28 & 13 \\
Direct approach & 16 & 7 \\
Community & 13 & 6 \\
$\quad$ organisations & 9 & 4 \\
Internet & 5 & 2 \\
Employment & & \\
$\quad$ agency & 4 & 2 \\
Others & 220 & 100 \\
Total & & \\
\hline
\end{tabular}


had access to the Internet at home (compared with 31 per cent who used the Internet on a regular basis to look for work) and a further 5 per cent reported owning a PC without an Internet connection. Estimates for current levels of 'connectedness' in Glasgow suggest that 31 per cent have Internet access, with a further 9 per cent owning a PC without access (MORI, 2003). It would appear that this sample of job seekers are not far below the city average (although it is important to stress again that Glasgow lags behind Scotland and the UK). Predictably, those with access to the Internet at home were significantly more likely (1 per cent level using chi-squared test) to use the Internet regularly to look for work (61 per cent, compared with 18 per cent of those without home Internet access).

It is argued above that both access to the Internet and the use of new technologies in job seeking are likely to be influenced by a range of aspects of 'technological capital', which define the digital divide as experienced by some job seekers. However, before turning to these issues in more detail, it may be worthwhile first considering the reasons given by job seekers themselves for their use or avoidance of ICT. The claims made for the Internet as a job-matching tool include that it will provide more information, more accessible information and better-quality information (Autor, 2001; Freeman, 2002). Glasgow job seekers using the Internet on a regular basis appear to have accepted the first two of these claims to varying degrees, but are more sceptical of the third. Of those using the Internet on at least a weekly basis to look for work, almost all interviewees (98 per cent) reported 'easy access to job information' as a key benefit, while 59 per cent considered 'accessing information about more vacancies' as similarly important. This compared with less than one-third (32 per cent) who considered 'accessing betterquality information' to be a key benefit of Internet job seeking. For many of these job seekers, the Internet seems not to have qualitatively improved the search process. This may reflect the view that the most accurate and valuable job information is often gleaned from personal contacts, such as employees within workplaces (see also Green et al., 2005), and that the Internet merely provides access to the same information available from existing formal sources (the quality and detail of which are controlled by recruiting employers). Nevertheless, job seekers viewed the Internet as expanding the range and number of vacancies that can be targeted, while (crucially) offering greater choice and convenience in terms of the time and location where job-search activities are undertaken.

Turning to those not using the Internet to look for work, the lack of interest or perceived need that is often cited as an important attitudinal element of the digital divide (see-for example, ONS, 2003) was less apparent here. When interviewees who did not use the Internet regularly were asked to identify barriers to Web-based job seeking, few mentioned a 'lack of need' ( 6 per cent) or 'lack of awareness of Internet services' (5 per cent). They were much more likely to identify practical barriers, specifically a 'lack of ICT skills' (52 per cent) and 'lack of access' (55 per cent). It has already been demonstrated that there is a significant relationship between Internet access and job seeking. However, it may also be the case that the economic, social and cultural elements of 'technological capital' discussed above impact upon both access to the Internet and its use as a job-search tool. There is a clear need to identify the role of these factors and the relationships between them. For example, those with lower household incomes (a key indicator of economic capital) tend to be both more likely to have experienced long-term unemployment and less likely to have access to the Internet at home. Yet, thus far it has remained unclear the extent to which the digital divide experienced by these individuals is a symptom of their long-term unemployment (in itself linked to lower educational attainment), their income, or a combination of these factors. The analysis below seeks to address these issues. 


\subsection{Employability, Technological Capital and the Digital Divide}

In order to test the association between the economic, social and cultural elements of 'technological capital' and Internet access and use, a binary logistic regression model was developed. Two regressions were carried out: the first using home Internet access as a dependent variable; the second using weekly use of the Internet for job seeking. Prior to the development of the regression model, a correlation matrix of potential variables was applied and variables that exhibited statistically significant correlations were removed. Both regressions were then run against six key job-seeker characteristics, selected as indicators of: economic capital (household income; unemployment duration, as a proxy for labour market attachment); cultural capital (perception of own ICT skills; level of qualification, as a proxy for general skills profile); and social capital (use of social networks to look for work; whether living alone). Clearly, these indicators can provide only a basic exploratory framework for investigating what is likely to be a more complex process involving a wider range of variables. Nevertheless, it is reasonable to hypothesise that income and attachment to the labour market, qualifications and skills, and levels of social inclusion or isolation will impact on how individuals look for work. These indicators can also be viewed as at least partly defining job seekers' broader employability, as elements of a mix of 'employability skills and attributes' and 'personal circumstances' (in terms of access to financial and social capital) that affect individuals' interactions with the labour market (McQuaid and Lindsay, 2005).

Two additional potentially important variables were added to the model: gender and age-group. In the latter case, unemployed job seekers were divided into 'core' (25-49) and 'non-core' (18-24 and 50+) agegroups. There is evidence that younger people are significantly more likely to use the Internet than older people (especially those aged 50 years and over) (Russell and Stafford, 2002; ONS, 2003; Owen et al., 2003). However, previous research with unemployed job seekers suggests that there is some doubt that age, presented as a continuous variable, is a useful indicator of ICT access (McQuaid et al., 2004) - the reality is that the digital divide among this group often affects both the young, who can lack the disposable income to access ICT, and older people, who may face skills barriers. Regression models run on this data-set with age as a continuous variable did not reveal statistically significant associations. Accordingly, an alternative 'core'-'non-core' agegroup variable was constructed.

As Table 4 shows, those in higher income-groups (selected as representative of

Table 4. Respondents with home internet access and using the Internet to look for work on a weekly basis, by selected individual characteristics

\begin{tabular}{lccccc}
\hline & \multicolumn{2}{c}{ Home internet access } & & \multicolumn{2}{c}{ Weekly internet use } \\
\cline { 2 - 3 } Job-seeker characteristic & \multicolumn{1}{c}{ Beta } & Significance & & Beta & Significance \\
\hline Income group & 0.295 & $0.065^{*}$ & & 0.489 & $0.007^{* * *}$ \\
Unemployment duration & -0.130 & 0.747 & & -0.963 & $0.024^{* *}$ \\
Level of qualification & 0.562 & $0.001^{* * *}$ & & 0.333 & $0.057^{*}$ \\
Perception of ICT skills & 0.295 & 0.237 & & 1.000 & $0.000^{* * *}$ \\
Use of social networks & 0.472 & 0.232 & & 0.452 & 0.283 \\
Living alone & -0.591 & 0.235 & & -0.752 & 0.158 \\
Male & 0.354 & 0.475 & & 0.413 & 0.448 \\
'Core' age-group & -0.351 & 0.378 & & 0.609 & 0.163 \\
Constant & -4.126 & $0.000^{* * *}$ & & -5.288 & $0.000^{* * *}$ \\
\hline
\end{tabular}

Notes: Beta co-efficients estimated from binary logistic regression.

${ }^{* * *} p<0.01 ;{ }^{* *} p<0.05 ;{ }^{*} p<0.10$. 
'economic capital') were significantly more likely both to have access to the Internet at home and to use Web-based job-search services. These findings concur with previous research undertaken in Glasgow, Scotland and the UK, highlighting the fundamental importance of income to Internet access (MORI, 2003; Scottish Executive, 2003; ONS, 2003). Scottish Household Survey figures for 2002 suggest that only 17 per cent of those with a weekly income of less than $£ 115$ had Internet access, half the then national average access rate of 34 per cent (Scottish Executive, 2003). Among the sample of job seekers analysed in this paper, only 21 per cent of those with a weekly income below $£ 100$ (then $€ 151$ ) had Internet access at home, compared with 39 per cent of those with higher incomes and a 31 per cent average for the total sample. Longer unemployment duration was negatively associated with Internet access and use (although only in the latter case significant at the 5 per cent level). It is perhaps surprising that unemployment duration was not significantly associated with a lack of home Internet access, but the manner in which the long-term unemployed were less likely to use Webbased services adds to existing evidence that many of these more disadvantaged job seekers will require assistance if they are to benefit from services delivered via ICT (Coleman et al., 2002; McQuaid et al., 2003).

In order to test the association between 'cultural capital' and ICT access and use a broad objective measure of educational attainment/skills (formal qualifications) was used alongside a subjective measure of confidence in the specific area of using new technologies (interviewees' perceptions of their own ICT skills). Those holding higher levels of qualification were significantly more likely to have access to the Internet at home and to use the Web to look for work on a regular basis-a finding that mirrors UK-level research on educational attainment and Internet use (ONS, 2002). However, the above findings also highlight the importance of job seekers' perceptions of their own skills-those rating their ICT skills as 'good' were also significantly more likely to use the Internet for job seeking. Selwyn (2002b) appears to have been justified in identifying individuals' 'self-image as an ICT user' as a potentially crucial component of the digital divide.

Finally, measures of 'social capital' did not emerge as significant predictors of ICT access and use, despite the argument that the extent and range of job seekers' contacts will affect their use of ICT. Using social networks on a weekly basis was associated with home Internet access and Web-based job seeking, but not significantly so. People living alone (and therefore potentially less likely to have extensive social networks) were also, as expected, less likely to have access to the Internet or to use it for job seeking, but this association was again not statistically significant. It would appear that, within the context of job seeking, Internet use and social networking play potentially important, but still separate, roles. Social capital may emerge as an important determinant of digital inclusion within broader social contexts and the Internet may eventually play a role facilitating informal job-search networking. However, within this urban labour market, job seekers continued to view the Internet primarily as a means of accessing formal job-search information and services. Neither gender nor membership of 'core' job-seeker age-groups emerged as significant predictors of home Internet access or using the Internet to look for work. The constants for both equations were statistically significant, with high negative values reflecting the general propensity within the sample to respond negatively regarding Internet access and use.

\section{Conclusions and Policy Implications}

The above findings highlight the extent to which a digital divide differentiates the experiences of unemployed people in relation to looking for work via the Internet. Further assistance is likely to be required if the unqualified, the low skilled, the long-term unemployed and those on low incomes are to be enabled to reap the benefits of new services and opportunities for job seeking through 
ICT. Aspects of economic and cultural capital-the access and skills barriers identified by unemployed people themselvesdefined job seekers' experiences of the digital divide. Social capital was a far less powerful predictor of Internet access and use, possibly because many unemployed people continue to view the Internet as a social technology or a job-search tool, but have yet to develop the 'virtual' contacts required to bring together social networking and job seeking as one on-line activity.

It should also be noted that Web-based job seeking remains the activity of a minority. For most unemployed people, across a range of skill sets and income-groups, Internet services and communications play little or no role in their job-search activities. New provision delivered through ICT offers job seekers an alternative to standard approaches to looking for work but, in the short term, face-to-face services provided by agencies such as Jobcentre Plus and 'traditional' informal methods are likely to retain their central role. Nevertheless, the digital divide identified above appears to operate among job seekers, rather than separating job seekers as a general group from the rest of society. Levels of Internet access among this sample of urban job seekers were only slightly lower than city-wide averages, although the study area was lagging behind national access rates at the time of the research.

Digital inclusion policies for job seekers should therefore target both the groups within the unemployed most in need of assistance and the urban and rural areas that are least 'connected' in terms of ICT access and use (of which the city of Glasgow is one example). Community-based ICT centres, offering an informal arena for social networking and peer support along with access and advice for users, have proved effective in some urban areas (Servon and Nelson, 2001; Devins et al., 2002). The value of such 'holistic, flexible, localised ICT provision' for disadvantaged areas and groups has been noted in evaluations of current digital inclusion initiatives in the UK (CLES Consulting et al., 2003; Hall Aitken, 2003).
Finally, there is a need for further research in this policy area. The limited sample for the study and its restriction to one urban area raises questions about the nature and extent of the digital divide encountered by job seekers in more 'connected' communities and the differences between cities and rural areas, where there may be more incentive to use Web-based services but also additional barriers in terms of weak communications or public access infrastructures. A further caveat should be acknowledged. All the respondents participating in the research had thus far been unsuccessful in finding work. There is a clear need for more detailed research on the relationship between ICT access and skills and job-search success, and the different ways that unemployed and in-work job seekers relate to Internet services.

Providing accurate, accessible labour market information is a priority for policymakers concerned with promoting employability. Delivering effective job-search services and access to vacancy information are therefore important elements in bridging the 'employability gap' and facilitating access to employment (McQuaid and Lindsay, 2002). New technologies represent an opportunity to develop the quality and expand the reach of services for job seekers in inner cities and other disadvantaged areas. However, if job seekers are to be encouraged to take up these opportunities, policies must continue to emphasise open access to ICT in appropriate formats and locations. An expansion of community-based initiatives in inner cities should be combined with a renewed commitment to promoting ICT skills and so an 'ICT user self-image' among the unemployed. Only by addressing the digital divide experienced by many of the most disadvantaged job seekers will policy-makers ensure that the potential employability gains offered by ICT-based services are exploited for the benefit of all unemployed people.

\section{References}

Autor, D. (2001) Wiring the labor market, Journal of Economic Perspectives, 15, pp. 35-40. 
Beatty, C., Fothergill, S., Gore, T. and GREEN, A. (2002) The real level of unemployment 2002. Sheffield: Sheffield Hallam University.

Belt, V. and Richardson, R. (2005) Social labour, employability and social exclusion: pre-employment training for call centre work, Urban Studies, 42(2), pp. 257-270.

BERG, L. VAN DEN and WINDEN, W. VAN (2002) Should cities help their citizens to adopt ICTs? On ICT adoption policies in European cities, Environment and Planning C, 20, pp. 263-279.

Bonfadelli, H. (2002) The Internet and knowledge gaps: a theoretical and empirical investigation, European Journal of Communication, 17 , pp. $65-84$.

Borgida, E., Sullivan, J. L., Oxendine, A. Et Al. (2002) Civic culture meets the digital divide: the role of community electronic networks, Journal of Social Issues, 58, pp. 125-142.

CABINET OFFICE (2002) Cabinet office service delivery agreement 2002/3 to 2005/6. London: Stationery Office.

Carter, C. and Grieco, M. (2000) New Deals, no wheels: social exclusion, tele-options and electronic ontology, Urban Studies, 37, pp. $1735-1748$.

Chadwick, A. and MAY, C. (2002) Interaction between states and citizens in the age of the Internet: e-Government in the United States, Britain and the European Union, Governance, 16 , pp. $271-300$.

Chapple, K. (2002) Out of touch, out of bounds: how social networks shape the labour market radii of women on welfare in San Francisco, Urban Geography, 22, pp. 617-640.

Cles Consulting, MCCR and CEMVO (2003) Supporting access to ICT for BME groups in deprived areas. Research Report 388, Department for Education and Skills, London.

Coleman, N., Jeenwody, F. and Wapshott, J. (2002) Electronic government at the Department for Work and Pensions: attitudes to electronic methods of conducting benefit business. Research Report 176, Department for Work and Pensions, London.

Corrigan, P. and Joyce, P. (2000) Re-connecting to the public, Urban Studies, 37, pp. 1771-1779.

DABinetT, G. (2002) Reflections on regional development policies in the information society, Planning Theory and Practice, 3, pp. $232-237$.

DAVIES, R. (2002) Making the most of IT: the role of local government in benefits take-up, Benefits, 10 , pp. $135-139$.

Devins, D., DARlow, A. and Smith, V. (2002) Lifelong learning and digital exclusion: lessons from the evaluation of an ICT Learning Centre and an emerging research agenda, Regional Studies, 36, pp. 941-945.
Devins, D., Darlow, A., Petrie, A. and Burden, T. (2003) Connecting communities to the Internet: an evaluation of the WiredUp Communities initiative. Research Report 389, Department for Education and Skills, London.

DFEs (DEPARTMENT FOR EDUCATION AND SKILls) (2002) Wired-up communities (www.dfes.gov. uk/wired/over.shtml).

DiMaggio, P., Hargittai, E., Neuman, W. R. and Robinson, J. (2001) Social implications of the Internet, Annual Review of Sociology, 27, pp. 307-336.

DTI (DEPARTMENT FOR TRADE AND INDUSTRY) (2000) Closing the digital divide: information and communication technologies in deprived areas. London: Stationery Office.

DWP (Department FOR WORK AND PEnsions) (2002) The Employment Service Annual Report and Accounts, 2001-02. London: Stationery Office.

Employment Service (2000) Modernising ES. Sheffield: Employment Service.

Freeman, R. B. (2002) The labour market in the new information economy, Oxford Review of Economic Policy, 18, pp. 288-305.

Futureskills Scotland (2003) Scottish labour market report 2003. Glasgow: Futureskills Scotland.

GHK (2002a) Jobseeker Direct customer satisfaction survey. Research Report 126, Employment Service, Sheffield.

GHK (2002b) Early views on the Internet job bank. Research Report 109, Employment Service, Sheffield.

GHK (2002c) Internet access for Jobcentre staff pilot evaluation. Research Report 110, Employment Service, Sheffield.

Graham, S. (2002) Bridging urban digital divides? Urban polarisation and information and communications technologies, Urban Studies, 39, pp. 33-56.

Green, A., Shuttleworth, I. and Lavery, S. (2005) Young people, job search and local labour markets: the example of Belfast, Urban Studies, 42(2), pp. 301-323.

Haddon, L. (2000) Social exclusion and information and communication technologies, New Media and Society, 2, pp. 387-406.

Hall AitKen (2003) Evaluation of CMFfunded uk on-line centres. Research Report 502, Department for Education and Skills, London.

HAMPTON, K. (2002) Place-based and IT-mediated 'community', Planning Theory and Practice, 3, pp. 228-231.

ILO (INTERNATIONAL LABOUR ORGANISATION) (2001) World Employment Report 2001: Life at Work in the Information Economy. Geneva: ILO. 
Johnson, S. and Burden, T. (2003) Young People, Employability and the Induction Process. York: Joseph Rowntree Foundation.

Katz, J., Rice, R. and Aspden, P. (2001) The Internet 1995-2000: access, civic involvement and social interaction, American Behavioural Scientist, 45, pp. 405-419.

KPMG (2002) Is Britain on course for 2005? London: KPMG.

Kraut, R., Lundmark, V., Patterson, M. et al. (1998) The Internet paradox: a social technology that reduces social involvement and psychological well being?, American Psychologist, 53, pp. 1017-1031.

Kuhn, P. and Skuterud, M. (2000) Job search methods: Internet versus traditional, Monthly Labor Review, 123, pp. 3-11.

Lindsay, C., McCracken, M. and McQuaid, R. W. (2003) Unemployment duration and employability in remote rural labour markets, Journal of Rural Studies, 19, pp. 187-200.

Loader, B., Muncer, S., Burrows, R. et al. (2002) Medicine on the line? Computermediated social support and advice for people with diabetes, International Journal of Social Welfare, 11, pp. 53-65.

MALECKI, E. (2003) Digital development in rural areas: potential and pitfalls, Journal of Rural Studies, 19, pp. 201-214.

MANSELl, R. (2002) From digital divides to digital entitlements in knowledge societies, Current Sociology, 50, pp. 407-426.

McKennA, K. Y. A. and Bargh, J. A. (2000) Plan 9 from cyberspace: the implications of the Internet for personality and social psychology, Personality and Social Psychology Review, 4, pp. 57-75.

McQuaid, R. W. and Lindsay, C. (2002) The 'employability gap': long-term unemployment and barriers to work in buoyant labour markets, Environment and Planning C, 20, pp. 613-628.

MCQuaid, R. W. and Lindsay, C. (2005) The concept of employability, Urban Studies, 42(2), pp. 197-219.

McQuaid, R. W., Lindsay, C. and Greig, M. (2003) Wired for Work? ICT and Job Seeking in Rural Areas. York: Joseph Rowntree Foundation.

McQuaid, R. W., Lindsay, C. and Greig, M. (2004) Re-connecting the unemployed: ICT and services for job seekers in rural areas, Information, Communication and Society, 7(3), pp. 364-388.

MeER, A. VAN DER and Winden, W. van (2003) E-governance in the cities: a comparison of urban information and communication technology policies, Regional Studies, 37, pp. 407-419.
MORI (MARKet AND OPINION RESEARCh INTERNAtional) (2003) Glasgow Panel Study, Autumn 2003. Glasgow: MORI/Glasgow City Council.

NiE, N. and ERbring, L. (2000) The Internet and Society. Stanford, CA: Institute for the Quantitative Study of Society.

Niles, S. and Hanson, S. (2003) The geographies of on-line job search: preliminary findings from Worcester, MA, Environment and Planning A, 35, pp. 1223-1243.

Norris, P. (2001) The Digital Divide: Civic Engagement, Information Poverty and the Internet Worldwide. New York: Cambridge University Press.

NTIA (NATIONAL Telecommunications AND INFORMATION ADMINISTRATION) (1999) Falling through the Net: defining the digital divide (http://www.ntia.doc.gov/ntiahome/dn/ index.html).

NTIA (2000) Falling through the Net: toward digital inclusion (http://www.ntia.doc.gov/ ntiahome/dn/index.html)

OECD (ORganisation FOR ECONOMIC CoOperation ANd Development) (2001) Understanding the Digital Divide. Paris: OECD.

ONS (OfFice fOR NAtional Statistics) (2002) Internet Access: Statistical First Release, September. London: ONS.

ONS (2003) Internet Access: Statistical First Release, December. London: ONS.

Owen, D., Green, A. E., Mcleod, M. et al. (2003) The use of and attitudes towards information and communication technologies (ICT) by people from black and minority ethnic groups living in deprived areas. Research Report 450, Department for Education and Skills, London.

PARKer, E. (2000) Closing the digital divide in rural America, Telecommunications Policy, 24, pp. 281-290.

RusSell, N. and StafFord, N. (2002) Trends in ICT access and use. Research Report 358, Department for Education and Skills, London.

ScOtTISH ENTERPRISE (2003) Digital inclusion audit, 2003. Glasgow: Scottish Enterprise.

Scottish Enterprise Glasgow (2003) Glasgow economic audit, 2003. Glasgow: Scottish Enterprise Glasgow.

Scottish Executive (2001) Scottish Economic Report. Edinburgh: Stationery Office Scotland.

Scottish Executive (2002) Digital communities initiative (www.scotland.gov.uk/digitalscotland/ digital_communities.asp).

Scottish Executive (2003) Scotland's PeopleResults from the 2001-2002 Scottish Household Survey. Edinburgh: Stationery Office Scotland.

Selwyn, N. (2002a) E-stablishing an inclusive society? Technology, social exclusion and UK government policy making, Journal of Social Policy, 31, pp. 1-20. 
SElwyn, N. (2002b) Defining the 'digital divide': developing a theoretical understanding of inequalities in the information age. Occasional Paper 49, School of Social Sciences, Cardiff University.

Servaes, J. and Heinderyckx, F. (2002) The 'new' ICTs environment in Europe: closing or widening the gaps?, Telematics and Informatics, 19 , pp. 91-115.

SERVON, L. J. (2002) Four myths about the digital divide, Planning Theory and Practice, 3, pp. 222-227.

Servon, L. J. and Nelson, M. K. (2001) Community technology centers and the urban technology gap, International Journal of Urban and Regional Research, 25, pp. 419-426.
Wellman, B. (2001) Physical space and cyber place: the rise of personalised networking, International Journal of Urban and Regional Research, 25, pp. 227-252.

Wellman, B., Haase, A., Witte, J. and HAMPTON, K. (2001) Does the Internet increase, decrease or supplement social capital? Social networks, participation and community commitment, American Behavioural Scientist, 45, pp. 436-455.

Winden, W. VAN (2001) The end of social exclusion? On information technology policy as a key to social inclusion in large European cities, Regional Studies, 35, pp. 861-877. 
